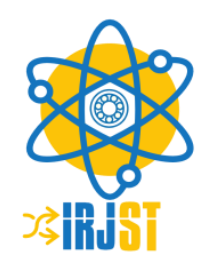

Available online at https://www.irjst.com/

International Research Journal of Science and Technology

ISSN: 2707-3955

DOI: https://doi.org/10.46378/irjst.2020.020105

\title{
A Review on the Medicinal and Aromatic Plants Growing in Libya and Their Therapeutic Properties.
}

\author{
Abdullah F Abogmaza ${ }^{1}$, Kheri F Keer ${ }^{2}$, Ayad A Takrizzah ${ }^{3}$, Esam Bashir Yahya ${ }^{{ }^{*}}$ \\ ${ }^{1}$ Faculty of Science, Al-asmarya Islamic University, Zliten, Libya \\ ${ }^{2}$ Faculty of Arts \& sciences, Al-Mergheb University, Kasr khiar, Libya \\ ${ }^{3}$ Faculty of Education, Al-asmarya Islamic University, Zliten, Libya
}

\begin{tabular}{lll}
\multicolumn{2}{l}{ Paper Status } & \\
Received & Nov 2020 \\
Accepted & $:$ & Dec 2020 \\
Published & $:$ & Dec 2020
\end{tabular}

Key Words

Aromatic

Libya

Medicinal Plant

Medical Properties

Traditional

\begin{abstract}
Plants are a rich source of diverse metabolites that have been traditionally used for thousands of years all over the world, providing safer and inexpensive therapeutic option for millions of people in developing countries including Libya. Many types of medicinal plants growing in Libya possess significantly important curative activities and have been traditionally used for treatment of chronic diseases such as diabetes and cancer, as well as their biological activities such as antibacterial, antifungal, antiparasitic and insecticidal properties, etc. Apart from the therapeutic activities, most of Libyan nation rather to use natural and plant-based materials for their daily activities such as food preservation, food flavoring as well as medicinal usages. This review presents the most important medicinal plants growing in Libya with their traditional usage, medical properties, and compare the reliability of using these plants as therapeutic agents. Presenting the latest works that have been done in term of justification of the traditional use and scientifically proving its ability as therapeutic agent
\end{abstract}

Copyright @ (2020: Abdullah F Abogmaza, Kheri F Keer, Ayad A Takrizzah, Esam Bashir Yahya. This is an open-access distribution, and reproduction in any medium provided Access article distributed under the Creative Commons Attribution License the original work is properly cited License, which permits unrestricted use.

Citation: Abdullah F Abogmaza, Kheri F Keer, Ayad A Takrizzah, Esam Bashir Yahya. "A Review on the Medicinal and Aromatic Plants Growing in Libya and Their Therapeutic Properties". International Research Journal of Science and Technology, 2 (1), 327--334, 2020.

\section{Introduction}

Numerous medicinal plants have long been traditionally utilized as therapeutic agents [1]. Various specialized metabolites have been isolated, which proved their medical activity such as anti-diabetic activity [2], antioxidant [3], anticancer activity [4], antibacterial activity [5], antifungal activity [6], antiparasitic activity [7], anti-inflammatory activity [8], wound healing $[9,10]$ and hypolipidaemic effects [11], etc. These metabolites are believed to be used by the plants as defence strategies to adapt and survive in different ecological situation and against different parasites [12].

\footnotetext{
* Corresponding Author: Esam Bashir Yahya

Faculty of Science, Al-asmarya Islamic University, Zliten,

Libya

Email: essam912013@gmail.com
}

The demand of safer and cheaper plant-based medicine, pharmaceuticals, food supplements, health products, cosmetics and nutraceuticals, are increasing and gaining more interest among the scientists worldwide [14]. In the current century, natural or plants-based products represent up to $50 \%$ of all drugs in hospitals and clinical use [15]. More than 50\% of the approved medicinal based drugs during the last 3 decades are directly or indirectly either from natural resources, including plants, animal and/or microorganisms [16].

Numerous wild plants in North Africa have a high potential value of medicinal and biotechnology use, more than 70000 different plant species worldwide have been considered as medicinal plants or at least involved in folk ethno therapy [17, 18]. However, medicinal and aromatic plants growing in Libya were first briefly mentioned in a the united nations 
educational, scientific and cultural organization report [19]. Mukassabi et al. [17] reviewed the morphological description, the medicinal values and active substance materials make-up of 93 wild poisonous plant species in Libya.

Despite the frequent and traditional use of these plants, there are a huge gaps of knowledge about the actual medicinal values of these plants in the region including their productivity, autecology, distribution and their possibility of cultivation [20]. Since, the establishment of the new national strategy in Libya, open and closed wild conservation areas, using the media to increase the public awareness of the importance and value of different wild plant species, which could conserve the vegetation and protect the country from the critical climate conditions [21, 22]. Not much have been recently done regarding presenting different types, properties and medicinal values of Libyan medicinal plants compared with their traditional use. Here, we aim to deliver summery on the commonest, high medicinal value of the plants growing all over Libya.

\section{Material and Methods}

The current research was conducted using several popular search engines including Science Direct, PubMed, Web of Science, and Scopus. It mainly focused on English and Arabic written research and review papers published in the past 20 years.

\section{Results and Discussion}

The results of our current investigation revealed to numerous plants with highly curative capacity for the treatment of major and minor human disease [23]. The finding revealed that most of nations preferred to use plants based therapeutics mainly to cure their wounds, and as antidiabetic. It has been reported by World Health Organization that the majority of population especially in developing countries including Libya chiefly depends on the traditional medicines and herbal drugs for treatment of primary health care requirements [24]. However, significant number of plants based drugs have been developed and introduced to the market, which gave a remarkable contribution to current therapeutics [25]. According to many sources such as $[17,26,27]$ the prevalence of usage was mainly among the elder peoples especially in the villages and rural regions, compared to the cities and the capital. Many medicinal plants growing in Libya have been found to carry many active compounds that have significant role in management of variety of human mild and chronic diseases such as microbial infections, inflammations, cancer, diabetes and so on [28, 29]. Figure 1 presents some of these widely growing plants and trees in different regions in Libya.

Three main local botanical habitats are present in Libya, for instance, the coastal and the desert habitats with their crossing valleys from south to north as well as from west to east, giving the chance for more than 1800 different plant species to grow, which are flourishing in these habitats [30]. Libyan people have been found to use medicinal plants and their based materials as medicinal supplements as many of them possess antiseptic, insecticidal and parasiticidal activities, which consider as nontoxic material and cost effective [31]. The presence of the active compounds polyphenol in many Libyan plants such as phenol and flavonoids, which contained high free radical scavenging molecule that are rich in antioxidant activities and thus have anticancer properties [32]. Table 1 presents the most abundant medicinal plants growing in Libya with their common Arabic name, traditional use, the main active compounds and the scientific medicinal and biological properties.

\section{Traditional use of Libyan Medicinal Plants from Scientific Aspect}

The development of medicinal plants or plant-based drugs started when development of chemistry, isolation, purification, characterization of plant active compounds. Many medicinal plants have been reported to have the ability to inhibit the production and expression of the pro-inflammatory mediators cytokines and TNF- $\alpha$, other plants have the ability to enhance the production of IFN- $\gamma$ [50]. Rahbardar et al. [51] investigated the anti-inflammatory effect of the widely growing in Libya medicinal plant Rosmarinus officinalis $L$. The authors reported that the laboratory rats exhibited a marked expression in the levels of inflammatory markers compared with the controls, on both days 7 and 14. The plant extract was able to significantly decrease the amounts of many inflammatory markers. Diabetes has become a major health problem in recent years worldwide, especially in the Middle East region; it is one of the five leading causes of death in the world [52]. The prevalence of this chronic disease in Libya attracted the attention of WHO, as it become a major health issue in the past 10 years. Traditionally, people in Libya use numerous of medicinal plants as an anti-diabetic agents. El Adib et al. [53] in vitro evaluated the inhibitory effect of leaf, seed, and pulp extracts of Argania spinosa L. against the enzyme $\alpha$-amylase related to diabetes. The authors reported strong activity of the plant to inhibit $\alpha$ amylase enzyme.

Edrah et al. [26] screened the phytochemical presents in Ephedra altissima from Libya, which is known in Libyan by local traditional name Khadraia and it is traditionally used to treat asthma, bronchitis issues as well as cold and flu. The authors extracted many active compounds that can significantly use to treat such diseases. Artemisia campestris $L$ is another antidiabetic medicinal plant commonly used in Libya and North Africa. 


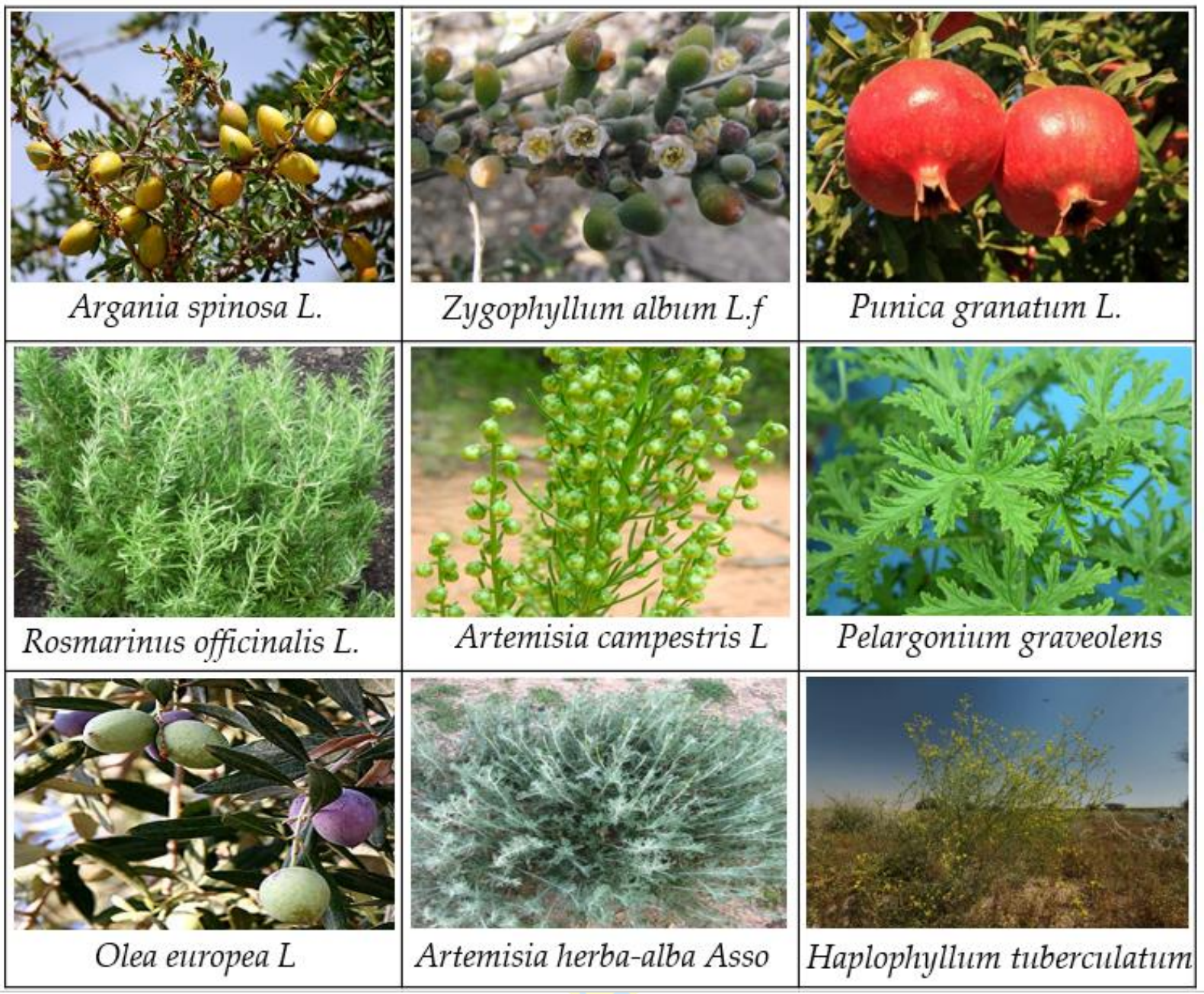

Figure 1. Medicinal and Aromatic Plants growing in Libya and North Africa

Table 1. Medicinal plants growing in Libya with their traditional use

\begin{tabular}{|c|c|c|c|c|c|}
\hline $\begin{array}{l}\text { Scientific } \\
\text { Name of Plant }\end{array}$ & $\begin{array}{l}\text { Common } \\
\text { And Arabic } \\
\text { Names }\end{array}$ & $\begin{array}{l}\text { Traditional } \\
\text { Use }\end{array}$ & Phytochemicals & $\begin{array}{l}\text { Medicinal And } \\
\text { Biological Properties }\end{array}$ & Ref \\
\hline $\begin{array}{l}\text { Anethum } \\
\text { graveolen L. }\end{array}$ & $\begin{array}{l}\text { Dill } \\
\text { الثبت }\end{array}$ & $\begin{array}{l}\text { digestive } \\
\text { disturbances, } \\
\text { insomnia and } \\
\text { urinary } \\
\text { infections }\end{array}$ & $\begin{array}{l}\text { Alkaloids, resin, } \\
\text { steroid, terpenoids, } \\
\text { flavonosides, } \\
\text { saponin, flavonoid, } \\
\text { and tannin. }\end{array}$ & $\begin{array}{l}\text { Insecticidal, } \\
\text { antimicrobial, anti- } \\
\text { inflamatory, } \\
\text { anticancer and } \\
\text { antidiabetic } \\
\text { activities }\end{array}$ & $\begin{array}{l}{[33,} \\
34]\end{array}$ \\
\hline $\begin{array}{l}\text { Pelargonium } \\
\text { graveolens } \\
\text { L'Her }^{\prime} \text { ' }\end{array}$ & $\begin{array}{l}\text { rose } \\
\text { geranium } \\
\text { العطر }\end{array}$ & $\begin{array}{l}\text { Various kinds } \\
\text { of } \\
\text { inflammatory } \\
\text { diseases }\end{array}$ & $\begin{array}{l}\text { Flavonoids, tannins, } \\
\text { geraniums, phenolic } \\
\text { acids and } \\
\text { proanthocyanidins }\end{array}$ & $\begin{array}{l}\text { Treatment of } \\
\text { diarrhea, diabetes, } \\
\text { gall bladder, } \\
\text { inflammation, liver, } \\
\text { and gastric ulcer }\end{array}$ & [35] \\
\hline $\begin{array}{l}\text { Acacia } \\
\text { saligna } \\
\text { (Labill.) }\end{array}$ & $\begin{array}{l}\text { Blue-Leaf } \\
\text { Wattle } \\
\text { سنط الإكليل }\end{array}$ & $\begin{array}{l}\text { Cracks of feet } \\
\text { and hands, } \\
\text { Abscess and } \\
\text { Constipation }\end{array}$ & $\begin{array}{l}\text { Polyphenols, 5- } \\
\text { glucoside, } \\
\text { rutoside, coumaric } \\
\text { and gallic acids, } \\
\text { hyperoside, } \\
\text { 3-glucuronide, } \\
\text { apigetrin and apigenin }\end{array}$ & $\begin{array}{l}\text { Strong antioxidant } \\
\text { activities, in addition } \\
\text { to } \\
\text { antibacterial, } \\
\text { antifungal and } \\
\text { anticancer activities }\end{array}$ & $\begin{array}{l}{[36]} \\
{[28]}\end{array}$ \\
\hline
\end{tabular}




\begin{tabular}{|c|c|c|c|c|c|}
\hline $\begin{array}{l}\text { Punica } \\
\text { granatum L. }\end{array}$ & $\begin{array}{l}\text { Pomegranate } \\
\text { الرمان }\end{array}$ & $\begin{array}{l}\text { Anti- } \\
\text { tapeworms, } \\
\text { diarrhea, } \\
\text { dysentery and } \\
\text { hemorrhages. }\end{array}$ & $\begin{array}{l}\text { Flavonoids; } \\
\text { anthocyanins } \\
\text { anthoxanthins, ellagic } \\
\text { acid, tannins; } \\
\text { phenolic acids and } \\
\text { ellagitannins. }\end{array}$ & $\begin{array}{l}\text { Strong antioxidant, } \\
\text { antibacterial, } \\
\text { antifungal, } \\
\text { anticancer, liver } \\
\text { problems \& allergies }\end{array}$ & $\begin{array}{l}{[37,} \\
38]\end{array}$ \\
\hline $\begin{array}{l}\text { Anastatica } \\
\text { hierochuntica } \\
\text { L. }\end{array}$ & $\begin{array}{l}\text { Rose of } \\
\text { Jericho } \\
\text { كف مريم }\end{array}$ & $\begin{array}{l}\text { Labour pain, } \\
\text { menstrual } \\
\text { cramps and } \\
\text { uterine } \\
\text { haemorrhage }\end{array}$ & $\begin{array}{l}\text { New skeletal } \\
\text { flavonoids, } \\
\text { lariciresinol, evofolin } \\
\text { B, balanophonin, rutin } \\
\text { kaempferol, and } \\
\text { luteolin }\end{array}$ & $\begin{array}{l}\text { Antioxidant and } \\
\text { antimicrobial } \\
\text { activities, } \\
\text { Hypoglycemic and } \\
\text { hypolipidaemic } \\
\text { effects }\end{array}$ & $\begin{array}{l}{[39,} \\
40]\end{array}$ \\
\hline $\begin{array}{l}\text { Viburnum } \\
\text { tinus L. }\end{array}$ & $\begin{array}{l}\text { Laurustinus } \\
\text { لور استينوس }\end{array}$ & $\begin{array}{l}\text { Gastritis and } \\
\text { anti- } \\
\text { inflammattory }\end{array}$ & $\begin{array}{l}\text { Iridoids, coumarins, } \\
\text { saponins, and } \\
\text { flavonoids }\end{array}$ & $\begin{array}{l}\text { Neuroprotective and } \\
\text { antioxidant activity, } \\
\text { diuretic, } \\
\text { antispasmodic and } \\
\text { sedative properties }\end{array}$ & $\begin{array}{l}{[41,} \\
42]\end{array}$ \\
\hline $\begin{array}{l}\text { Olea europea } \\
L\end{array}$ & $\begin{array}{l}\text { Olive } \\
\text { الزينون }\end{array}$ & $\begin{array}{l}\text { Heart disease, } \\
\text { anti-diabetic } \\
\text { and anti-cancer }\end{array}$ & $\begin{array}{l}\text { Polyphenols, tyrosol, } \\
\text { hydroxytyrosol, } \\
\text { Quercetin, oleuropein, } \\
\text { rutin, and apigenin }\end{array}$ & $\begin{array}{l}\text { Antioxidant, anti- } \\
\text { diabetic, } \\
\text { cardioprotective and } \\
\text { anti-inflammatory }\end{array}$ & $\begin{array}{l}{[43,} \\
44]\end{array}$ \\
\hline $\begin{array}{l}\text { Trigonella } \\
\text { foenum- } \\
\text { graecum L. }\end{array}$ & $\begin{array}{l}\text { Fenugreek } \\
\text { الحلبة }\end{array}$ & $\begin{array}{l}\text { Anti-diabetic } \\
\text { and digestive } \\
\text { disturbances }\end{array}$ & $\begin{array}{l}\text { Alkaloids, saponins, } \\
\text { steroids, tannins, } \\
\text { flavonoids, amino } \\
\text { acids and trigonilline. }\end{array}$ & $\begin{array}{l}\text { Anti-inflammatory, } \\
\text { cholesterol lowering } \\
\text { agent, anti-diabetic, } \\
\text { liver disorder and as } \\
\text { an anti-fertility } \\
\text { agent. }\end{array}$ & {$[45]$} \\
\hline $\begin{array}{l}\text { Scabiosa } \\
\text { arenaria } \\
\text { Forssk. }\end{array}$ & $\begin{array}{l}\text { Scabiosa } \\
\text { arenaria } \\
\text { Forssk. }\end{array}$ & $\begin{array}{l}\text { Anti-diabetic } \\
\text { and respiratory } \\
\text { problems }\end{array}$ & $\begin{array}{l}\text { Phenolic compounds, } \\
\text { triterpene saponins, } \\
\text { and ursolic acid. }\end{array}$ & $\begin{array}{l}\text { Antidiabetic, } \\
\text { bronchial } \\
\text { pneumonia, } \\
\text { bronchitis, influenza } \\
\text { and asthma }\end{array}$ & {$[46]$} \\
\hline $\begin{array}{l}\text { Rosmarinus } \\
\text { officinalis L. }\end{array}$ & $\begin{array}{l}\text { Rosemary } \\
\text { اكليل الجبل }\end{array}$ & $\begin{array}{l}\text { To treat otitis, } \\
\text { auricular, liver, } \\
\text { dermatoses, } \\
\text { cough cold, } \\
\text { and asthma }\end{array}$ & $\begin{array}{l}\text { Flavones, flavonols, } \\
\text { flavanones, } 5 \\
\text { phenolic acids, } \\
\text { diterpenoids, } 1 \\
\text { triterpenoid and } 3 \\
\text { lignans }\end{array}$ & $\begin{array}{l}\text { Antioxidant, anti- } \\
\text { cancer, anti- } \\
\text { inflammatory and } \\
\text { antimicrobial }\end{array}$ & [47] \\
\hline $\begin{array}{l}\text { Artemisia } \\
\text { herba-alba } \\
\text { Asso }\end{array}$ & $\begin{array}{l}\text { Desert } \\
\text { Wormwood } \\
\text { الثيح }\end{array}$ & $\begin{array}{l}\text { Anti- } \\
\text { tapeworms, } \\
\text { diarrhea, and } \\
\text { digestive } \\
\text { disturbances }\end{array}$ & $\begin{array}{l}\text { Flavonoids } \\
\text { phenolics, volatile } \\
\text { and essential oils. }\end{array}$ & $\begin{array}{l}\text { Antinociceptive, } \\
\text { antiviral, } \\
\text { antidiabetic, } \\
\text { anticancer, } \\
\text { antibacterial and } \\
\text { antioxidant }\end{array}$ & [48] \\
\hline $\begin{array}{l}\text { Haplophyllum } \\
\text { tuberculatum }\end{array}$ & $\begin{array}{l}\text { Meseika } \\
\text { صنان التيس }\end{array}$ & $\begin{array}{l}\text { Arthritis, skin } \\
\text { discoloration } \\
\text { and } \\
\text { antiparasites }\end{array}$ & $\begin{array}{l}\text { Alkaloids: } \\
\text { haplophytin A \&B, } \\
\text { flindersine, oleanolic, } \\
\text { kusunokinin, } \beta \text { - } \\
\text { sitosterol, cholesterol } \\
\text { and hexadecanoic } \\
\text { acids }\end{array}$ & $\begin{array}{l}\text { Anti-cancer, uterus- } \\
\text { relaxing, } \\
\text { antioxidantant } \\
\text { antibacterial } \\
\text { activities }\end{array}$ & [49] \\
\hline
\end{tabular}

The administration of the aqueous extract of from Artemisia campestris $L$ to alloxan-induced diabetic rats at a dose of $200 \mathrm{mg} / \mathrm{kg}$ resulted in a significant reduction in glycemia [54]. Zygophyllum album L.f have been used to reduce blood sugar in many parts in the Mediterranean see especially in Tunisia, Libya, Algeria and Morocco. It is also used for other purposes such as an antioxydant and antilipedimic [55]. Accordingly to traditional medicine, many research has proven that the ethanolic extract of this plant was 
significantly able to reduce plasma glucose level in streptozocin diabetic mice when it consumed for 14 days [55]. One recent study was conducted on the administration to the essential oil of Zygophyllum album L.f for 30 days, the diabetic rates after alloxan treatment, showed an excellent effect in the management of diabetes, the essential oil was able to inhibit many digestive enzymes such as $\alpha$-amylase [56].

Punica granatum L. traditionally used in Libya to treat digestive issues as well as antibacterial and antiinflammatory agent, its commonly used in north Africa as well as Turkey and Iran. Lansky et al. [57] investigated the potential use of Punica granatum $L$. extract for treatment of cancer and inflammations. The authors concluded that the phytochemistry and pharmacological actions of the compounds present in all Punica granatum suggest a wide range of medicinal use and clinical applications, for treatment of chronic inflammations and for the treatment and prevention of cancer. Trigonella foenum-graecum L.is a famous medicinal plant in Libya for its potential in treatment of type II diabetes. Many people have use it and still using this medicinal plant as a herbal tea to reduce their blood sugar. Lu et al. [58] investigated this potential by conducting a study on sixty-nine type II diabetic patients whose blood glucose levels were not well controlled. The authors revealed that there were statistically remarkable decreases in the $\mathrm{HbAlc}$ in the treated group as compared to those in the control group, concluding a great potential for this plant to lower the blood glucose level and ameliorate clinical symptoms in the treatment of type II diabetes.

Pelargonium graveolens $L^{\prime} H e r$ is an aromatic plant used in Libya as flavoring agent in tea and for wound treatment as antibacterial material. Bouzenna et al. [59] and Pradeepa et al. [60] confirmed the antifungal and antibacterial activity of Pelargonium graveolens respectively. The two studies revealed that the plant extract was able to kill the microorganisms (fungicidal and bactericidal activities). Medicinal plants have been used since thousands of years and still in use until today, many current works have proven their activity as therapeutic agents.

\section{Conclusions}

Herbal medicine based on different aromatic and medicinal plants is effective, lesser side effect, and affordable than the medicines bought from an allopathic medicine. It has been used since ancient for different mild and severe health issues. As developing country, Libyan nation seemed to be dependent on the medicinal plants, as a safer and cost effective option. They have been used different medicinal plants as antibacterial, wound treatment agents, antidiabetic, and even anticancer materials. The activity of different used types of Libyan medicinal plants have been scientifically proved, as they possess many secondary metabolites. It has been well documented that medicinal plants and their derivatives play critical roles in modern drug development. Medicinal plants growing in Libya have the potential to be an important natural resources in developing of new drugs.

\section{Acknowledgements}

The authors express their profound sense of gratitude and to Department of Botany, Faculty of Sciences, Al-asmarya Islamic University, and to thank the collaboration between the Al-Mergheb University and Al-asmarya Islamic University that has made this work possible.

\section{References}

[1]. Hao, D.-C. and P.-G. Xiao, Genomics and evolution in traditional medicinal plants: road to a healthier life. Evolutionary Bioinformatics, 2015. 11: p. EBO. S31326.

[2]. Salehi, B., et al., Antidiabetic potential of medicinal plants and their active components. Biomolecules, 2019. 9(10): p. 551.

[3]. Pisoschi, A.M., et al., Antioxidant capacity determination in plants and plant-derived products: A review. Oxidative medicine and cellular longevity, 2016. 2016.

[4]. Akhtar, M.S. and M.K. Swamy, Anticancer plants: natural products and biotechnological implements. Vol. 920. 2018: Springer.

[5]. Yahya, E. and M.A. Abdulsamad, In-vitro Antibacterial Activity of Carbopol-Essential Oils hydrogels. Journal of Applied Science \& Process Engineering, 2020. 7(2): p. 564-571.

[6]. Lagrouh, F., N. Dakka, and Y. Bakri, The antifungal activity of Moroccan plants and the mechanism of action of secondary metabolites from plants. Journal de mycologie medicale, 2017. 27(3): p. 303-311.

[7]. Tariq, A., et al., Ethnomedicines and antiparasitic activities of Pakistani medicinal plants against Plasmodia and Leishmania parasites. Annals of clinical microbiology and antimicrobials, 2016. 15(1): p. 52.

[8]. Kazemi, S., H. Shirzad, and M. RafieianKopaei, Recent findings in molecular basis of inflammation and anti-inflammatory plants. Current pharmaceutical design, 2018. 24(14): p. 1551-1562.

[9]. Yahya, E.B., et al., Antibacterial cellulosebased aerogels for wound healing application: A review. Biomedical Research and Therapy, 2020. 7(10): p. 4032-4040.

[10]. Yahya, E.B., et al., A review on revolutionary natural biopolymer-based aerogels for antibacterial delivery. Antibiotics, 2020. 9(10): p. 648 . 
[11]. Airaodion, A.I., et al., Hypoglycemic and hypolipidaemic activities of methanolic extract of Talinum triangulare leaves in Wistar rats. International Journal of Bio-Science and BioTechnology, 2019. 11(5): p. 1-13.

[12]. Dar, R.A., M. Shahnawaz, and P.H. Qazi, General overview of medicinal plants: A review. The Journal of Phytopharmacology, 2017. 6(6): p. 349-351.

[13]. Bukhari, N., et al., Prevalence of Human Papilloma Virus Sub Genotypes following Head and Neck Squamous Cell Carcinomas in Asian Continent, A Systematic Review Article. Asian Pacific Journal of Cancer Prevention: APJCP, 2019. 20(11): p. 3269.

[14]. 14. Yahya, E.B., et al., Growth rate and antibiotic sensitivity effect of some natural and petroleum based materials on Staphylococcus aureus. International Journal for Research in Applied Sciences and Biotechnology, 2020. 7(5): p. 7-11.

[15]. Shakya, A.K., Medicinal plants: future source of new drugs. International Journal of Herbal Medicine, 2016. 4(4): p. 59-64.

[16]. Yahya, E.B., et al., The Effect of Natural and Petroleum Based Materials on the Growth Rate and Antibiotic Sensitivity of Pseudomonas aeruginosa. International Journal for Research in Applied Sciences and Biotechnology, 2020. 7(5): p. 295-298.

[17]. Mukassabi, T.A., P.A. Thomas, and A. Elmogasapi, Medicinal plants in Cyrenaica, Libya: existence and extinction. Biological Diversity and Conservation, 2017.

[18]. 18. Abdul Khalil, H., et al., A Review on plant cellulose nanofibre-based aerogels for biomedical applications. Polymers, 2020. 12(8): p. 1759.

[19]. Vilarnau, C., et al., Worldwide adherence to Mediterranean Diet between 1960 and 2011. European journal of clinical nutrition, 2019. 72(1): p. 83-91.

[20]. Dakeel, E., M. Alaib, and A. Asker, Comparative Study of Medicinal Plants in Al Mansora and Jarjar oma, Al Jabal Al Akhdar, Libya [Version 1; awaiting peer review]. ContROL, 2017. 1: p. 4.

[21]. Rizal, S., et al., Properties of Macroalgae Biopolymer Films Reinforcement with Polysaccharide Microfibre. Polymers, 2020. 12(11): p. 2554.

[22]. Almashgab, A.M., E.B. Yahya, and A. Banu, The Cytotoxicity Effects of Outer Membrane Vesicles Isolated from Hospital and Laboratory Strains of Pseudomonas Aeruginosa on Human Keratinocyte Cell Line. Malaysian Journal of Science, 2020: p. 45-53.
[23]. Aftab, T., A review of medicinal and aromatic plants and their secondary metabolites status under abiotic stress. Journal of Medicinal Plants, 2019. 7(3): p. 99-106.

[24]. Ashur, S.T., et al., Use of traditional medicine among type 2 diabetic Libyans. Eastern Mediterranean Health Journal, 2017. 23(5).

[25]. 25.Cheraghi, M. and M. Asadi-Samani, Hematopoietic medicinal plants based on ethnobotanical documents of Iran: A strategy to develop nature-based drugs effective on anemia. Der Pharmacia Lettre, 2016. 8(5): p. 393-399.

[26]. Edrah, S.M., et al., Qualitative and quantities analysis of phytochemicals of various extract for Ephedra altissima from Libya. Journal of Medicinal Plants Studies, 2016. 4(3): p. 119121.

[27]. Koerper, H. and A. Kolls, The silphium motif adorning ancient Libyan coinage: marketing a medicinal plant. Economic botany, 1999. 53(2): p. 133-143.

[28]. El-Mokasabi, F.M., M.F. Al-Sanousi, and R.M El-Mabrouk, Taxonomy and Ethnobotany of Medicinal Plants in Eastern Region of Libya. J. Environ. Sci. Toxicol. Food Technol., 2018. 12: p. 14-23.

[29]. Kollab, W.A. and S.M. Alamen, Qualitative and quantitative screening of the chemical components for selected medicinal plants from Libya. Journal of Medicinal Plants, 2018. 6(1): p. 92-95.

[30]. Mahalouf, M. and K.S. Etayeb, Biodiversity in Libya. Global Biodiversity, 2018. 3.

[31]. Bobaker, A.M., et al., Determination and Assessment of the Toxic Heavy Metal Elements Abstracted from the Traditional Plant Cosmetics and Medical Remedies: Case Study of Libya. International journal of environmental research and public health, 2019. 16(11): p. 1957.

[32]. Duletić-Laušević, S., et al., Composition and biological activities of Libyan Salvia fruticosa Mill. and S. lanigera Poir. extracts. South African Journal of Botany, 2018. 117: p. 101109.

[33]. Altameme, H.J., I.H. Hameed, and L.F. Hamza, Anethum graveolens: Physicochemical properties, medicinal uses, antimicrobial effects, antioxidant effect, anti-inflammatory and analgesic effects: A review. International Journal of Pharmaceutical Quality Assurance, 2017. 8(03): p. 88-91.

[34]. Ewase, A.E.-d.S., et al., Effect of salinity stress on Dill seeds germination and growth in vivo in Libya. The Scientific Journal of the 
University of Benghazi SJUB EDITORIAL BOARD: p. 4.

[35]. Ennaifer, M., et al., Phytochemicals, antioxidant, anti-acetyl-cholinesterase, and antimicrobial activities of decoction and infusion of Pelargonium graveolens. Natural product research, 2020. 34(18): p. 2634-2638.

[36]. Elansary, H.O., et al., Antioxidant and biological activities of Acacia saligna and Lawsonia inermis natural populations. Plants, 2020. 9(7): p. 908.

[37]. Singh, B., et al., Phenolic compounds as beneficial phytochemicals in pomegranate (Punica granatum L.) peel: A review. Food chemistry, 2018. 261: p. 75-86.

[38]. Yahya, E.B., et al., Evaluation of in-vitro Antibacterial Activity of Aqueous and Alcoholic Extracts of the Peels Punica Granatum and Olea Europaea Leaves. Journal of Sciences and Technologies (Medical Science), 2018. 2(1).

[39]. Zin, S.R.M., et al., Biological activities of Anastatica hierochuntica L.: A systematic review. Biomedicine \& Pharmacotherapy, 2017. 91: p. 611-620.

[40]. Abd El-Ghani, M.M., et al., The Inland Eastern Desert of Egypt, in Plant Responses to Hyperarid Desert Environments. 2017, Springer. p. 83-177.

[41]. Cometa, M., G. Mazzanti, and L. Tomassini, Sedative and spasmolytic effects of Viburnum tinus L. and its major pure compounds. Phytotherapy Research: An International Journal Devoted to Pharmacological and Toxicological Evaluation of Natural Product Derivatives, 1998. 12(S1): p. S89-S91.

[42]. Y1lmaz, B.S., et al., Enzyme inhibitory and antioxidant activities of Viburnum tinus L. relevant to its neuroprotective potential. Food chemistry, 2013. 141(1): p. 582-588.

[43]. Zern, T.L. and M.L. Fernandez, Cardioprotective effects of dietary polyphenols. The Journal of nutrition, 2005. 135(10): p. 2291-2294.

[44]. Maalej, A., et al., Assessment of Olea europaea L. fruit extracts: Phytochemical characterization and anticancer pathway investigation. Biomedicine \& Pharmacotherapy, 2017. 90: p. 179-186.

[45]. Kadam, V.B., Phytochemical Profile of Trigonella foenum graecum Linn. International Journal of Pharmaceutics \& Pharmacology, 2018. 2(2).

[46]. Kılınç, H., et al., Phytochemical investigation of Scabiosa sicula guided by a preliminary HPLC-ESIMSn profiling. Phytochemistry, 2020. 174: p. 112350.
[47]. Mena, P., et al., Phytochemical profiling of flavonoids, phenolic acids, terpenoids, and volatile fraction of a rosemary (Rosmarinus officinalis L.) extract. Molecules, 2016. 21(11): p. 1576.

[48]. Bellili, S., et al., Phytochemical identification of volatile fraction, essential oil and screening of antioxidant, antibacterial, allelopathic and insecticidal potential from Artemisia herbaalba leaves. Main Group Chemistry, 2017. 16(2): p. 95-109.

[49]. Raissi, A., et al., Haplophyllum tuberculatum: An overview. Journal of HerbMed Pharmacology, 2016. 5(4): p. 125-130.

[50]. 50.Luetragoon, T., et al., Bioactive compounds in Moringa oleifera Lam. leaves inhibit the pro-inflammatory mediators in lipopolysaccharide-induced human monocytederived macrophages. Molecules, 2020. 25(1): p. 191.

[51]. Rahbardar, M.G., et al., Anti-inflammatory effects of ethanolic extract of Rosmarinus officinalis $\mathrm{L}$. and rosmarinic acid in a rat model of neuropathic pain. Biomedicine \& Pharmacotherapy, 2017. 86: p. 441-449.

[52]. Care, F., Standards of Medical Care in Diabetes 2019. Diabetes Care, 2019. 42(Suppl 1): p. S124-S138.

[53]. El Adib, S., et al., Argania spinosa var. mutica and var. apiculata: Variation of Fatty- Acid Composition, Phenolic Content, and Antioxidant and $\alpha$ - Amylase- Inhibitory Activities among Varieties, Organs, and Development Stages. Chemistry \& biodiversity, 2015. 12(9): p. 1322-1338.

[54]. Sefi, M., et al., Mitigating effects of antioxidant properties of Artemisia campestris leaf extract on hyperlipidemia, advanced glycation end products and oxidative stress in alloxan-induced diabetic rats. Food and chemical toxicology, 2010. 48(7): p. 19861993.

[55]. El Ghoul, J. and M. Ben-Attia, Vasorelaxant effects of aqueous extract of Zygophyllum Album and antihyperglycemic activities in streptozotocin-induced diabetic mice. J. Diabetes Metab, 2014. 5: p. 426.

[56]. Mnafgui, K., et al., Essential oil of Zygophyllum album inhibits key-digestive enzymes related to diabetes and hypertension and attenuates symptoms of diarrhea in alloxan-induced diabetic rats. Pharmaceutical biology, 2016. 54(8): p. 1326-1333.

[57]. 57.Lansky, E.P. and R.A. Newman, Punica granatum (pomegranate) and its potential for prevention and treatment of inflammation and 
cancer. Journal of ethnopharmacology, 2007. 109(2): p. 177-206.

[58]. 58.Lu, F.-r., et al., Clinical observation on trigonella foenum-graecum L. total saponins in combination with sulfonylureas in the treatment of type 2 diabetes mellitus. Chinese Journal of Integrative Medicine, 2008. 14(1): p. $56-60$.

[59]. 59.Bouzenna, H. and L. Krichen, Pelargonium graveolens L'Her. and Artemisia arborescens L. essential oils: chemical composition, antifungal activity against Rhizoctonia solani and insecticidal activity against Rhysopertha dominica. Natural product research, 2013. 27(9): p. 841-846.

[60]. 60.Pradeepa, M., V. Kalidas, and N. Geetha, Qualitative and quantitative phytochemical analysis and bactericidal activity of Pelargonium graveolens L'Her. Int J Appl Pharm, 2016. 8(3): p. 7-11.

\section{E- Journals}

[1]. Chris Wilson and Pallikada Vathsaseendran, a paradox within a paradox: scheduled caste fertility in kerala published by economic and political weekly.stable.

url:http://www.jstor.org/stable /4416878.

[2]. Davidkent "peri://www.athiest community .org/stable/library/articles/read.php.id

=710 retrieved 06-21-2007.yar aca.http.

[3]. Dipanker gupta, Caste and politics: identity over system published by annual reviews stable.

url://www.jstor.org/stable/25064892.

[4]. George Varghese, Globalization Trumans and new social imaginary.

[5]. Election guide, Election cellof malayala manorama Trivandrum 2011.

[6]. Gough, e.kathleen, Nayars: century, Kerala in Schneider, davidmurray, gough, e.kathleen.matrine al kingship university of California press.isbn.

[7]. Jeffry robin, the decline of nair dominance: society and politics in Travancore 1847-1908.sussex university press.

[8]. Mohindra k.s, d.narayana and haddad slim, Evidence based public health and practice, women's health in a rural community in kerala, India: do caste and socio-economic position matter.j epidemonial community health 2006.
[9]. Mohanty manoranjan, Class, caste and genter, Sage publications newdelhi thousands oaks London 2004.

[10]. Nossiter Thomas Johnson, Keralas's identity: unity and diversity ".communism in kerala: a study in political adaptation.university of California press ISBN 9780520046672.

[11]. Sitush, Caste system in kerala, Wikipedia, the free encyclopedia (talks and contributions) 3 seconds time http://www.vivekananda.net/pdf books/from Colombo to almora.pdf.

[12]. Syamlal, Untouchables caste in India, the raigar movement (1940-2004), rawat publications newdelhi 2006.

\section{Internet Sources}

[1]. Directory 2010-2011 the free encyclopedia en.wikipedia.org.

[2]. Directory 2011 Diocese of Alleppey kerala, India, bishop house p b no: 4804.

[3]. http://www.vivekananda.net/pdf books/from Colombo to almora.pdf.

[4]. Wikipedia, the free encyclopedia en.wikipedia.org/wiki/p.parameswara. 